\title{
Effect of Feeding Safflower Cake with or without Enzymes on Performance of Broiler Chickens
}

\author{
C. D. Solanke, M. R. Wade*, B. S. Barmase and N. V. Nemade \\ Poultry Research Center, Department of Poultry Science, Post Graduate Institute of \\ Veterinary and Animal Sciences, Akola (Maharashtra) - 444 104, India \\ *Corresponding author
}

\begin{tabular}{l} 
K e y w o r d s \\
Broilers, Safflower, \\
Enzyme, \\
Performance \\
Article Info \\
$\begin{array}{l}\text { Accepted: } \\
26 \text { March } 2020 \\
\text { Available Online: } \\
\text { 10 April } 2020\end{array}$ \\
\hline
\end{tabular}

\section{A B S T R A C T}

The present study was carried out to evaluate the effect of enzyme supplementation on utilization of Safflower cake safflower cake replacing soybean de-oiled cake and without enzyme on the performance of commercial broiler chicken. Four hundred straight run commercial day-old broiler chicks were equally and randomly distributed into five treatment groups which were subdivided into four replicates containing 20 chicks in each, reared on deep litter The enzyme-Natuzyme@ $0.035 \%$ supplemented groups had non significantly higher body weight in comparison to birds in control groups. The body weight, weight gain, feed intake and feed efficiency in all the treatment groups were comparable with the control group. Better feed efficiency was observed in birds fed $50 \%$ safflower DOC on protein basis with enzyme group. The maximum dressing yield was observed in group fed $25 \%$ safflower DOC on protein basis group $\mathrm{T}_{1}$. Addition of safflower DOC either at $50 \%$ or $25 \%$ with enzyme was found to be cost effective. Soybean de-oiled cake in broiler diets may be replaced up to $25 \%$ on protein basis by with enzymes for optimum performance in broiler chicken

\section{Introduction}

Global demand for broiler meat is touching to new heights every day. Though broiler industry is a profitable agro-business increasing cost of feed is a problem faced by the poultry farmers because protein and energy components of poultry diets on tribute between 80 and $90 \%$ of total value of layer or broiler diet. High protein ingredients are much expensive than low protein ingredients. Among plant protein sources commonly used ingredient in poultry rations is soybean meal. However, soybean seed has anti-nutritional factors such as trypsin inhibitors which need further processing, thus increasing the cost of 
feed. Therefore, the focus of scientists has been on utilization of locally available unconventional feedstuffs like safflower cake/ sunflower cake by using various feed enzymes. Safflower cake is mostly used as a protein ingredient for animal feeding. Seed and cake of safflower contain high level of non-starch polysaccharides (NSP) and phytic acid which act as anti-nutritional factors (Daffaalla et al., 2015). The exogenous enzymes mproved dietary nutrient utilization and digestibility of energy, fat and protein (Adeol and Bed Ford, 2004). The enzymes also lowers feed cost and help in reducing the environmental pollution and thereby minimizing the waste excretion (Sinha et al., 2013).The present experiment was planned to assess the effect of level of safflower cake in diet with and without addition of multienzymes on the performance of broilers.

\section{Materials and Methods}

Four hundred Mareks Disease vaccinated dayold broiler straight run commercial chicks were procured from private hatchery. The chicks were equally and randomly distributed into five treatment groups with four replicates having 20 chicks in each replicate. These chicks were reared on deep litter system in pens up to 6 weeks of age and were vaccinated against Ranikhet and Gumboro disease vaccines at $7^{\text {th }}$ and $14^{\text {th }}$ day of age, respectively. Uniform and standard management practices were provided throughout the experimental period i.e. up to 6 weeks of age for all the treatment groups. The dietary treatment groups were: basal diet of soybean DOC without safflower DOC and without enzymes $\left(\mathrm{T}_{0}\right)$, diet containing safflower DOC replacing soybean DOC @ 25 $\%\left(\mathrm{~T}_{1}\right)$ and @ $50 \%\left(\mathrm{~T}_{2}\right)$ on protein basis, diet containing safflower DOC replacing soybean DOC @ $25 \%$ with enzyme (Natuzyme) addition@0.035\% ( $\left.\mathrm{T}_{3}\right)$ and @ $50 \%$ with enzyme@ $0.035 \&\left(\mathrm{~T}_{4}\right)$ on protein basis groups respectively. Water was provided adlib to birds of all the treatment groups throughout the experimental period. Prestarter feed was provided to the broilers up to 7 days, followed by starter and finisher feed in which safflower cake was included by replacing soybean meal from second to third and fourth to sixth weeks of age, respectively. A multiple enzyme preparation, Natuzyme (Bioproton Pvt. Ltd., Sunnybank, Australia) was used as additive.

Birds from each group were weighed individually on day 0 and at weekly intervals. Live body weight gain (g/bird) was recorded in the study. Measured quantity of feed was offered every day and the left over feed was recorded after $24 \mathrm{hrs}$. The difference between the feed offered and balance feed was worked out to know the actual feed consumed by each group on a particular day. The feed consumption was calculated and expressed as $\mathrm{g} / \mathrm{bird}$. On the basis of weekly live weight and weekly feed consumption, the values of FCR of each group were calculated. The feed cost per $\mathrm{kg}$ body weight gain in broilers reared under different treatment regimen of the study was calculated based on feed consumption during the 0- 42 day period. The data obtained on various parameters studied during this experimental trial were subjected to statistical analysis (Snedecor and Cochran, 1994).

\section{Results and Discussion}

\section{Body weight and weight gain}

The highest body weight was observed in group fed diet containing safflower cake replacing soybean DOC @ $25 \%$ on protein basis plus addition of enzyme @ $0.035 \%\left(\mathrm{~T}_{3}\right)$, followed by the diet containing safflower replacing soybean DOC @ $50 \%$ on protein basis with the addition of enzyme @ $0.035 \%$ $\left(\mathrm{T}_{4}\right)$, while the lowest body weight was noted in group $\mathrm{T}_{2}$ (Table 1). The results indicated 
that there is non-significant difference in all the treatment groups. The diets containing safflower replacing soybean meal @ 25 and $50 \%$ on protein basis (group $\mathrm{T}_{1}$ and $\mathrm{T}_{2}$ ) showed slight growth retardation in broilers that might have been due to presence of more fiber, anti-nutritional factors, phenolic glucosides and bitter taste (Oguz and Oguze, 2007, Malakian et al., 2011). The enzyme supplementation of safflower diets showed slight improvement in live body weights of broilers, which may be due to partial cleavage of non-starch polysaccharides by enzymes, thereby removing anti-nutritive activity by increasing the digestibility of ingredients and availability of nutrient (Alam et al., 2003). These findings are in accordance with the reports of Daffaalla et al., (2015) (Table 2).

\section{Cumulative feed consumption}

There were significant differences in cumulative feed consumption among the different treatment groups (Table 1). However, non-significant difference was observed between the safflower dietary $\left(\mathrm{T}_{3}\right.$ and $\mathrm{T}_{4}$ ) groups, with enzyme supplementation. The birds receiving the control diet had highest cumulative feed consumption which differed significantly from the other groups. The birds fed with safflower diets consumed less feed than control group. However, the present findings are in agreement with Rehman and Malik (1986) who observed that diet containing safflower meal with or without enzyme significantly reduced feed intake. Sawarkar (2000) reported that safflower diet with enzymes could not improve the feed consumption in broilers. The present findings are in contradiction with Lazaro et al., (2003) and Daffaalla et al., (2015), who observed significant effect of enzyme on feed intake. The possible reason for reduced feed consumption may be that safflower cake has slightly bitter taste and contains more fiber (Oguz and Oguz, 2007).

\section{Feed conversion ratio}

There were non-significant differences in FCR among all the treatment groups. Slightly better feed efficiency was shown by $\mathrm{T}_{3}$ group (25\% SFM with enzyme) followed by $\mathrm{T}_{4}$ and $\mathrm{T}_{1}$ groups. The present findings are in contradiction to More (1995) and Oguz and Oguz (2007), who observed superior feed efficiency of safflower diet over control group. However, Rehman and Malik (1986) and Malakian et al., (2011) reported significantly reduced feed conversion efficiency in safflower based diet. Daffaalla et $a l$., (2015) reported significantly higher feed conversion ratio (FCR) for chicks fed on diets containing safflower cake with enzyme compared to control group.

\section{Dressing percentage}

There were non-significant differences in dressing percentage among all treatment groups. The maximum dressing yield was observed in safflower $25 \%$ on protein basis group $_{1}(67.00 \pm 0.70 \%)$, followed by control group $\mathrm{T}_{0}(66.00 \pm 1.52 \%)$ and the lowest dressing yield $(64.85 \pm 0.51 \%)$ was found in group $\mathrm{T}_{4}$. The present findings are in agreement with Rehman and Malik (1986), Malakian et al., (2011) and Daffaalla et al., (2015) who observed non-significant difference in dressing yield. However, these results are in contradiction to Alam et al., (2003), who observed increased dressing yield by the addition of exogenous enzymes. 
Table.1 Ingredient and nutrient composition of experimental diets (\% DM basis)

\begin{tabular}{|c|c|c|c|c|c|c|c|c|c|c|}
\hline \multirow{2}{*}{$\begin{array}{l}\text { Sr. } \\
\text { No. }\end{array}$} & \multirow{2}{*}{$\begin{array}{c}\text { Ingredients } \\
(\%)\end{array}$} & \multicolumn{3}{|c|}{ Prestarter } & \multicolumn{3}{|c|}{ Starter } & \multicolumn{3}{|c|}{ Finisher } \\
\hline & & Diet 1 & Diet 2 & Diet 3 & Diet 1 & Diet 2 & Diet 3 & Diet 1 & Diet 2 & Diet 3 \\
\hline 1 & Maize, yellow & 54.15 & 53.45 & 51.65 & 56.85 & 55.18 & 53.63 & 57.19 & 58.39 & 56.64 \\
\hline 2 & Soybean meal & 41.40 & 30.23 & 20.26 & 37.62 & 28.62 & 19.92 & 34.97 & 24.52 & 16.32 \\
\hline 3 & $\begin{array}{l}\text { Safflower } \\
\text { cake, DOC }\end{array}$ & 0 & 11.37 & 22.74 & 0 & 10.05 & 20.1 & 0 & 9.25 & 18.5 \\
\hline 4 & Veg Oil & 0.7 & 0.8 & 1.2 & 1.78 & 2 & 2.2 & 3.8 & 3.8 & 4.10 \\
\hline 5 & $\begin{array}{l}\text { Dicalcium } \\
\text { phosphate }\end{array}$ & 1.5 & 1.9 & 1.9 & 1.5 & 1.9 & 1.9 & 1.79 & 1.79 & 2.19 \\
\hline 6 & $\begin{array}{l}\text { Limestone } \\
\text { powder }\end{array}$ & 1.5 & 1.5 & 1.5 & 1.5 & 1.5 & 1.5 & 1.5 & 1.5 & 1.5 \\
\hline 7 & Common salt & 0.3 & 0.3 & 0.3 & 0.3 & 0.3 & 0.3 & 0.3 & 0.3 & 0.3 \\
\hline 8 & $\begin{array}{l}\text { DL- } \\
\text { Methionine }\end{array}$ & 0.2 & 0.2 & 0.2 & 0.2 & 0.2 & 0.2 & 0.2 & 0.2 & 0.2 \\
\hline 9 & $\begin{array}{l}\text { Vitamin } \\
\text { Mixure and } \\
\text { feed } \\
\text { supplements }\end{array}$ & 0.15 & 0.15 & 0.15 & 0.15 & 0.15 & 0.15 & 0.15 & 0.15 & 0.15 \\
\hline 10 & $\begin{array}{l}\text { Trace Mineral } \\
\text { Mixure }\end{array}$ & 0.10 & 0.10 & 0.10 & 0.10 & 0.10 & 0.10 & 0.10 & 0.10 & 0.10 \\
\hline & Total & 100 & 100 & 100 & 100 & 100 & 100 & 100 & 100 & 100 \\
\hline \multicolumn{11}{|c|}{ Nutrients } \\
\hline 1 & ME, Kcal/kg & 3014 & 3011 & 3011 & 3100 & 3105 & 3102 & 3219 & 3216 & 3218 \\
\hline & $\begin{array}{l}\text { Crude } \\
\text { protein,\% }\end{array}$ & 23.01 & 23.03 & 23.06 & 22.03 & 22.07 & 22.01 & 20.10 & 20.12 & 20.10 \\
\hline 2 & Calcium, \% & 1.0 & 1.0 & 1.0 & 1.0 & 1.0 & 1.0 & 1.0 & 1.0 & 1.0 \\
\hline 3 & $\begin{array}{l}\text { Available } \\
\text { Phosphorus \% }\end{array}$ & 0.56 & 0.58 & 0.56 & 0.56 & 0.56 & 0.55 & 0.56 & 0.57 & 0.58 \\
\hline 4 & L-Lysine, \% & 1.2 & 1.1 & 1.1 & 1.2 & 1.1 & 1.0 & 1.1 & 1.0 & 1.0 \\
\hline 5 & $\begin{array}{l}\text { DL- } \\
\text { Meth+Cyst., } \\
\%\end{array}$ & 0.76 & 0.8 & 0.8 & 0.78 & 0.8 & 0.9 & 0.77 & 0.78 & 0.8 \\
\hline
\end{tabular}


Table.2 Growth performance of broiler chicken fed Safflower DOC based diet with or without enzyme-Natuzyme @ 0.035\%

\begin{tabular}{|c|c|c|c|c|c|}
\hline \multirow[b]{2}{*}{$\begin{array}{l}\text { Parameter } \\
(0 \text { - } 6 \text { Weeks) }\end{array}$} & \multicolumn{5}{|l|}{ Treatment } \\
\hline & $\begin{array}{l}\text { Control- } \\
\text { Soybean } \\
\text { DOC, basal } \\
\operatorname{diet}\left(\mathrm{T}_{0}\right)\end{array}$ & $\begin{array}{l}\text { Safflower } \\
\text { DOC } \\
\text { replacing } \\
\text { soybean } \\
\text { DOC } \\
\text { @ } 25 \%\left(\mathrm{~T}_{1}\right)\end{array}$ & $\begin{array}{l}\text { Safflower } \\
\text { DOC } \\
\text { replacing } \\
\text { soybean } \\
\text { DOC @ 50\% } \\
\left(\mathrm{T}_{2}\right)\end{array}$ & $\begin{array}{l}\text { Safflower } \\
\text { DOC } \\
\text { replacing } \\
\text { soybean DOC } \\
@ 25 \%+ \\
\text { Enzyme }\left(\mathrm{T}_{3}\right)\end{array}$ & $\begin{array}{l}\text { Safflower } \\
\text { DOC } \\
\text { replacing } \\
\text { soybean DOC } \\
@ 50 \%+ \\
\text { Enzyme }\left(\mathrm{T}_{4}\right)\end{array}$ \\
\hline $\begin{array}{l}\text { Body weight } \\
\text { (g) }\end{array}$ & $\begin{array}{c}1860.0 \pm \\
6.34\end{array}$ & $\begin{array}{c}1849.0 \pm \\
6.63\end{array}$ & $\begin{array}{c}1810.75 \\
\pm 2.25\end{array}$ & $\begin{array}{c}1864.50 \\
\pm 3.68\end{array}$ & $\begin{array}{c}1860.25 \\
\pm 6.72\end{array}$ \\
\hline $\begin{array}{l}\text { Body weight } \\
\text { gain (g) }\end{array}$ & $\begin{array}{c}1798.21 \pm \\
7.86\end{array}$ & $\begin{array}{c}1798.75 \pm \\
7.06\end{array}$ & $\begin{array}{c}1760.5 \pm \\
7.01\end{array}$ & $\begin{array}{c}1806.74 \pm \\
6.49\end{array}$ & $\begin{array}{c}1816.08 \pm \\
11.98\end{array}$ \\
\hline $\begin{array}{l}\text { Cumulative } \\
\text { feed } \\
\text { consumption } \\
\text { (g) }\end{array}$ & $\begin{array}{c}3722.00^{c} \\
\pm 26.96\end{array}$ & $\begin{array}{l}3704.25^{\mathrm{c}} \\
\pm 21.55\end{array}$ & $\begin{array}{l}3521.00^{\mathrm{a}} \\
\pm 5.92\end{array}$ & $\begin{array}{c}3685.75^{\mathrm{bc}} \\
\pm 15.20\end{array}$ & $\begin{array}{c}3614.00^{b} \\
\pm 44.10\end{array}$ \\
\hline $\begin{array}{l}\text { Cumulative } \\
\text { feed efficiency }\end{array}$ & $2.06 \pm 0.05$ & $2.05 \pm 0.03$ & $2.00 \pm 0.1$ & $2.04 \pm 0.06$ & $1.99 \pm 0.02$ \\
\hline $\begin{array}{l}\text { Dressing } \\
\text { percentage }\end{array}$ & $66.00 \pm 1.52$ & $67.00 \pm 0.70$ & $65.66 \pm 1.20$ & $65.82 \pm 1.52$ & $64.85 \pm 0.51$ \\
\hline
\end{tabular}

Means bearing common superscripts do not differ significantly $(\mathrm{P}<0.05)$.

\section{Economics}

Safflower DOC @ 50\% with enzyme and safflower DOC @ $25 \%$ with enzyme groups have given good returns as compared to other experimental groups. profit per $\mathrm{kg}$ live body weight of broilers was observed in $\mathrm{T}_{4}$ group (Rs. 13.93) in which soybean DOC was replaced by safflower cake @ $50 \%$ on protein basis plus addition of enzyme @ $0.035 \%$, followed by group $T_{3}$ (Rs. 13.78) in which soybean DOC was replaced by safflower cake (a) $25 \%$ on protein basis plus addition of enzyme@ @ $0.035 \%$, while the lowest profit was obtained in control group $\mathrm{T}_{0}$ (Rs. 9.94).

In conclusions, addition of safflower DOC either at $50 \%$ or $25 \%$ with enzyme was found to be cost effective. Soybean de-oiled cake in broiler diets may be replaced up to 25
$\%$ on protein basis by with enzymes for optimum performance in broiler chicken

\section{Acknowledgements}

We gratefully thank Dean, Post Graduate Institute of Veterinary and Animal Sciences, Akola for the funds and facilities provided for this work.

\section{References}

Adeola,O.and M.R.Bed Ford 2004. Exogenous dietary xylanase ameliorates viscosity -induced anti- nutritional effects in wheat base diets for white pekin ducks. British Journal Nutrition, 92: 87-94

Alam, M. J., Howlider, M. A. R., Pramanik, M. A. H. and Haque, M. A. 2003. Effect 
of exogenous enzyme in diet on broiler performance. Int. Journal of Poultry Science, 2(2): 168-173.

Daffa alla, A.A., Mukhtar, A. M. and Mohamed, K.A. 2015. Response of broiler chicks to dietary safflower cake with and without enzyme. International Journal of Biological \& Pharmaceutical Research, 6(2): 91-95.

Lazaro, R., Garcia, M., Medel, P. and. Mateos. G.G. 2003. Influence of enzymes on performance and digestive parameters of broilers fed rye-based diets. Poultry Science, 82: 132-140.

Malakian, M., Hassanabadi, A. and Heidarinia, A. 2011. Effect of safflower seed on performance, carcass trait and blood parameter of broilers. Research Journal Poultry Science. 4 : 18-21.

More, D.M. 1995. Studies on partial replacement of groundnut cake by safflower cake in broilers ration. M.V.Sc. Thesis, submitted to Dr. Panjabrao Deshmukh Krishi Vidyapeeth, Akola (M.S.).
Oguz, F.K. and Oguz, M.N. 2007. The effect of safflower seed on performance and some blood parameters of broiler chicks. Indian Veterinary Journal. 84: 610-612.

Rehman, A. and Malik, M.Y. 1986. Safflower meal as a protein source in broiler rations. Pakistan Journal of Biochemistry, 19: 39-42.

Sawarkar, R.R. 2000. Effect of enzyme supplementation on safflower based diet in broilers. M.V.Sc. thesis submitted to Dr. PDKV. Akola.

Sinha, S.K., Sinha, A.K., Mahto, D.K., Ranjan, Rajeev. 2013. Effects of nonstarch polysaccharides hydrolysing enzymes on replacement of groundnut cake with okara meal in broiler birds .Indian Journal of Animal Nutrition, 30(2): 204-209

Snedecor, G.W. and Cochran, W.G. 1994 Statistical methods, 8th Edn. Lowa State University, Press USA. Oxford and IBH Publication New Delhi : 591.

\section{How to cite this article:}

Solanke, C. D., M. R. Wade, B. S. Barmase and Nemade, N. V. 2020. Effect of Feeding Safflower Cake with or without Enzymes on Performance of Broiler Chickens. Int.J.Curr.Microbiol.App.Sci. 9(04): 2982-2987. doi: https://doi.org/10.20546/ijcmas.2020.904.349 